\title{
Meningkatkan Kemampuan Motorik Halus Anak Melalui Teknik Mozaik di Raudhatul Athfal Nurul Huda Kecamatan Sunggal kabupaten Deli Serdang (Juli Maini Sitepu \& Sri Rahayu Janita)
}

\section{Meningkatkan Kemampuan Motorik Halus Anak Melalui Teknik Mozaik Di Raudhatul Athfal Nurul Huda Kecamatan Sunggal Kabupaten Deli Serdang}

\author{
Juli Maini Sitepu dan Sri Rahayu Janita \\ Dosen Program Studi Pendidikan Guru Raudhatul Athfal UMSU \\ (Email: Syaqibahsiregar@gmail.com)
}

\begin{abstract}
Abstrak
Penelitian ini dilaksanakan di Raudhatul Athfal Nurul Huda yang bertujuan untuk meningkatkan kemampuan motorik halus anak melalui teknik mozaik di Raudhatul Athfal Nurul Huda Kecamatan Sunggal Kabupaten Deli Serdang. Adapun jenis penelitian ini adalah penelitian tindakan kelas (Classroom Action Research). Pendekatan yang dilakukan adalah pendekatan kulitatif dan kuantitatif yang mengarah pada peningkatan kemampuan motorik halus anak melalui teknik mozaik. Adapun instrumen yang digunakan pada penelitian ini adalah berupa tes, lembar observasi, dan dokumentasi. Penelitian ini terdiri dari tiga sikulus, yang terdiri dari empat tahapan yaitu perencanaan, pelaksanaan, pengamatan, refleksi, juga disertai dengan pembahasan. Adapun yang menjadi subjek peneliti dari penelitian ini adalah siswasiswi Raudhatul Athfal Nurul Huda Kecamatan Sunggal Kabupaten Deli Serdang yang berjumlah 20 orang. Hasil penelitian menunjukkan bahwa adanya peningkatan kemampuan motorik halus anak melalui tehnik mozaik di Raudhatul Athfal Nurul Huda, pada kondisi awal (pra siklus) sebesar $31,25 \%$, meningkat pada siklus I menjadi $42,5 \%$, pada siklus II kemampuan motorik halus anak bertambah menjadi 66,25 \% dan pada siklus III meningkat menjadi $82,50 \%$.

Kata Kunci $\quad$ : Motorik Halus, Tehnik Mozaik

Korespondensi : Fakultas Agama Islam Universitas Muhammadiyah Sumatera

Utara. Jalan Kapten Mukhtar Basri No.03 Medan

\section{A. Pendahuluan}

Usia dini merupakan periode awal yang paling penting dan mendasar di sepanjang rentang pertumbuhan dan perkembangan kehidupan manusia. Pada masa ini ditandai oleh berbagai periode penting yang fundamen dalam kehidupan anak selanjutnya sampai

periode akhir perkembangannya. Salah satu periode yang menjadi penciri masa usia dini adalah The Golden Ages atau periode keemasan. ${ }^{2}$ Banyak konsep dan fakta yang ditemukan memberikan penjelasan periode keemasan pada masa usia dini, dimana semua potensi anak berkembang paling cepat. Oleh
\end{abstract}


karena itu peran serta pemerintah maupun orang tua dalam pertumbuhan dan perkembangan anak sangat dibutuhkan, supaya anak bisa berkembang, cerdas, serta dapat mengembangkan potensinya secara optimal. Hal ini merupakan pentingnya pendidikan untuk anak usia dini.

Dalam Peraturan Menteri Pendidikan Nasional Republik Indonesia No. 58 Tahun 2009 tentang Standar PAUD, meliputi 5 aspek pengembangan yaitu, nilai moral agama, fisik kognitif, bahasa, dan sosial emosional. Salah satu pengembangan tersebut terdapat di dalam bidang pengembangan fisik motorik. Perkembangan fisik motorik adalah perkembangan jasmaniah melalui kegiatan pusat saraf, urat saraf dan otot yang terkoordinasi. Gerak tersebut berasal dari perkembangan refleks dan kegiatan yang telah ada sejak lahir. Perkembangan fisik motorik terdiri atas dua jenis, yakni motorik kasar dan motorik halus. Gerak motorik kasar bersifat gerakan utuh, sedangkan gerakan motorik halus lebih bersifat

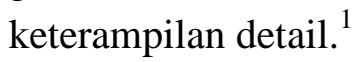

Motorik halus adalah penggunaan sekelompok otot-otot kecil seperti jari jemari dan tangan yang sering membutuhkan kecermatan dan

\footnotetext{
${ }^{1}$ Mustofa, Yasin. 2007. EQ Untuk Anak

Usia Dini Dalam Pendidikan Islam.
}

Yogyakarta : Sketsa, h. 101 koordinasi dengan tangan, keterampilan yang mencakup pemanfaatan dengan alat-alat untuk mengerjakan suatu objek. ${ }^{2}$ Motorik halus berkaitan dengan kegiatan yang menggunakan otot halus seperti : menggambar, menggunting, menempel dan lain sebagainya. Keterampilan yang mencakup pemanfaatan dengan alat-alat atau media untuk kegiatan pembelajaran misalnya menggunting, menempel, menulis, menggambar, dan lain-lain. Kegiatan-kegiatan yang mencakup pemanfaatan tersebut, misalnya dengan teknik mozaik. Gambar dengan teknik mozaik merupakan salah satu teknik menempel yang anak tidak diberi tugas untuk menggambar secara langsung, melainkan tugas anak adalah membuat bentuk gambar sesuai dengan pola yang disediakan, dan menempel dari berbagai media. Teknik mozaik pada anak RA adalah bagaimana cara menjiplak pola, yaitu memegang pensil, menebalkan sesuai garis, dan menyelesaikan garis pola. Caramenggunting pola, yaitu memegang gunting dengan benar, menggunting sesuai garis dan menggunting dengan rapi. Cara menjumput pola yang sudah digunting dengan lima jari, tiga jari dan dua jari.

\footnotetext{
$\begin{array}{lll}2011 . & \text { Trianto. Desain }\end{array}$ Pengembangan Pembelajaran Tematik. Jakarta : Prenada Media Group, h. 16
} 


\section{Meningkatkan Kemampuan Motorik Halus Anak Melalui Teknik Mozaik di Raudhatul Athfal Nurul Huda Kecamatan Sunggal kabupaten Deli Serdang (Juli Maini Sitepu \& Sri Rahayu Janita)}

Cara menempel pola, yaitu memberi lem pada pola, menempel pola dan menyelesaikannya.

\section{B. Landasan Teoretis}

\section{Perkembangan Motorik Halus} Anak

Motorik Halus adalah pengorganisasian penggunaan sekelompok otot-otot kecil seperti jari jemari dan tangan yang sering membutuhkan kecermatan dan koordinasi mata dengan tangan, keterampilan yang mencakup pemanfaatan menggunakan alat-alat untuk mengerjakan suatu objek. $^{3}$ Motorik halus juga dapat diartikan sebagai kemampuan anak beraktivitas dengan menggunakan otot-otot halus seperti menulis, meremas, menggenggam, menggambar, menempel, menyusun balok dan memasukkan kelereng. ${ }^{4}$

Perkembangan gerak motorik halus adalah meningkatnya pengordinasian gerak tubuh yang melibatkan otot dan saraf yang jauh lebih kecil atau detail. Kelompok otot dan saraf inilah yang nantinya mampu

${ }^{3}$ Wuryandari, Wuri. 2010. Penanaman

Nilai Moral Untuk Anak Usia Dini. Jawa Barat : PG TK IT Pusda, h. 32

4 Syafaruddin, dkk. 2013. Profesi Keguruan \& Pendalaman Materi Raudhatul Atfal. Medan : Fakultas Ilmu Tarbiah dan Keguruan IAIN, h. 154. mengembangkan gerak motorik halus, seperti meremas kertas, menyobek, menggambar dan lain sebagainya. ${ }^{5}$

Terdapat dua dimensi dalam perkembangan motorik halus anak yaitu :

1. Kemampuan memegang dan memanifulasi benda-benda.

2. Kemampuan dalam koordinasi mata dan tangan.

Beberapa dimensi perkembangan motorik halus anak :

a. Melakuakan kegiatan dengan satu lengan, seperti mencoretcoret dengan alat tulis.

b. Membuka halaman buku berukuran besar satu persatu.

c. Memakai dan melepas sepatu berperekat/tanpa tali.

d. Memakai dan melepas kaos kaki.

e. Memutar pegangan pintu

f. Memutar tutup botol

g. Melepas kancing jepret.

h. Mengancingkan/membuka velcro dan resleting (misalnya pada tas).

i. Melepas celana dan baju sederhana.

j. Membangun menara dari 4-8 balok.

5 Sumantri, MS. 2010. Model Pengembangan Keterampilan Motorik Anak Usia Dini. Jakarta : Depdiknas, Dirjen Dikti, h. 146 
k. Memegang pensil/krayon besar.

1. Mengaduk dengan sendok ke dalam cangkir.

m. Menggunakan sendok dan garpu tanpa menumpahkan makanan.

n. Menyikat gigi dan menyisir rambut sendiri.

o. Memegang gunting dan mulai memotong kertas.

p. Menggulung, menguleni, menekan, dan menarik adonan atau tanah liat.

2. Tujuan Peningkatan Motorik Halus

Tujuan pengembangan

motorik halus anak di usia 4-6 tahun adalah :

a. Anak mampu mengembangkan kemampuan motorik halus yang berhubungan dengan keterampilan gerak kedua tangan

b. Anak mampu menggerakkan anggota tubuh yang berhubungan dengan gerak jari seperti menulis, menggambar.

c. Mampu mengkoordinasi indra mata dan aktivitas tangan.

d. Anak mampu mengendalikan emosi dalam beraktivtas motorik halus. $^{6}$

$$
\text { Sedangkan tujuan }
$$

pengembangan motorik halus ialah :

a. Mampu memfungsikan otot-otot kecil seperti gerak jari tangan.

\footnotetext{
${ }^{6}$ Ibid, h. 146
}

b. Mampu mengkoordinasi kecepatan tangan dengan mata

c. Mampu mengendalikan emosi. ${ }^{7}$ Tujuan pengembangan motorik halus untuk anak usia dini adalah :

a. Sebagai alat untuk pengembangan keterampilan gerak kedua tangan.

b. Anak dapat menciptakan suatu hasil karya yang orisinil dari anak tersebut.

c. Sebagai alat untuk pengembangan koordinasi kecepatan tangan dan kecepatan mata.Untuk menyeimbangkan penglihatan pada saat seorang guru menggunakan metode demontrasi dalam pengembangan motorik halus anak.

d. Sebagai alat untuk melatih penguasaan emosi anak.

e. Karena dalam membuat hasil karya untuk anak usia dini sangan menguras emosi anak karena pada dasarnya egosentrisnya sangat tinggi.

Berdasarkan uraian di atas, dapat ditegaskan bahwa tujuan pengembangan motorik halus

7 Nuraida, Nia. 2012. Meningkatkan Keterampilan Motorik Halus melalui Metode Demonstrasi di TK Ilam Terpadu At-Taqwa. Jurnal Penelitian. Bandung : UPI, h. 132 
adalah membantu mengembangkan berbagai potensi anak baik psikis dan fisik yang meliputi moral dan nilai-nilai agama, sosial emosional, kognitif, bahasa, fisik/motorik, kemandirian, dan seni untuk memasuki pendidikan dasar.

\section{Aktivitas Motorik Halus Anak}

\section{Usia Dini}

Aktivitas motorik halus yang dimaksud pada anak usia dini meliputi:

(a) menggunting, (b) melipat, dan (menulis). ${ }^{8}$

a. Menggunting

Kegiatanmenggunting tidak hanya menyenangkan, kegiatan menggunting juga melatih keterampilan motorik halus anak. Mulai dari garis lurus, garis zigzag, garis lengkung, bentuk geometri hingga pola hewan. Kegiatan menggunting ini bertujuan untuk melatih koordinasi tangan dan mata yang merupakan persiapan menulis.

b. Melipat

Melipat pada hakikatnya merupakan kegiatan keterampilan tangan untuk menciptakan bentukbentuk tertentu tanpa menggunakan lem atau perekat.

Keterampilan ini membutuhkan keterampilan koordinasi tangan, ketelitian dan kerapihan serta kreativitas kegiatan

\footnotetext{
${ }^{8}$ Ibid, h. 145
}

melipat jika disajikan sesuaidengan minat anak, akan memberikan keasyikan dan kegembiraan serta kepuasan.

Melipat merujuk pada seni melipat kertas adalahmenjadikan suatu bentuk atau gambaran tertentu. Bentuk yang dimaksud bisa berupa hewan, tumbuhan, ataupun benda tertentu. Dalam melipat dibutuhkan ketelitian, kesabaran, dan ketekunan. Selain menyenangkan, kegiatan ini memiliki banyak manfaat lain, di antaranya dapat meningkatkan kreativitas dan motorik halus anak. Kegiatan melipat ini bertujuan melatihkan koordinasi mata dan otot-otot tangan serta konsentrasi. Aspek yang dinilai dalam kegiatan melipat ini adalah ketepatan mengikuti perintah, kerapihan hasil lipatannya dan antusiasme.

c. Menulis

Menulis adalah menurunkan atau melukiskan lambang-lambang grafik yang menggambarkan suatu bahasa yang dipahami oleh seseorang, sehingga orang lain dapat membaca lambang-lambang grafik tersebut kalau mereka memahami bahasa dan grafik tersebut. Pada dasarnya pembelajaran menulis di TK dapat dilaksanakan selama dalam batasbatas aturan pengembangan motorik anak usia TK. 


\section{Teknik Mozaik}

Secara terminologi Mozaik berasal dari kata "Mouseios" (yunani), yang berarti kepunyaan para Muse (sekelompok dewi yang melambangkan seni). Sedangkan dalam dunia seni, menurut Sunaryo Mozaik diartikan sebagai suatu jenis karya seni dekorasi yang menerapkan teknik tempel. Mozaik merupakan gambar atau hiasan atau pola tertentu yang dibuat dengan cara menempelkan bahan/unsur kecil sejenis (baik bahan, bentuk, maupun ukurannya) yang disusun secara berdempetan pada sebuah bidang. Mozaik menggunakan potonganpotongan kecil yang biasanya dikenal sebagai Tesserae (potongan kecil), yang digunakan untuk membuat pola atau gambar. $^{9}$

Gambar Mozaik adalah gambar yang ditempelkan dengan cara menempelkan potongan-potongan bahan pewarna (biasanya bahan kertas), atau butiran-butiran warna (biasanya biji-bijian), baik ditempelkan pada kertas, karton, papan triplek, maupun permukaan benda-benda perkakas seperti cobek, kendi, vas bunga dan sebagainya.

\section{Manfaat dan Tujuan Teknik Mozaik}

\section{Manfaat kegiatan Mozaik sangat}

\footnotetext{
${ }^{9}$ Muharrar, Syakir \& Verayanti, Sri.
} 2013. Kreasi Kolase, Montase, Mozaik Sederhana. Jakarta : Erlangga, h. 35 banyak untuk anak, karena Mozaik mengasah kreatifitas anak dalam membentuk suatu karya yang bagus dengan cara menempelkan suatu benda kecil ke suatu media. Kegiatan Mozaik memiliki manfaat untuk anak usia dini diantaranya :

a. Pengenalan bentuk. Dalam kegiatan Mozaik manfaat yang bisa kita dapat adalah kita bisa mengenalkan pada anak tentang macam-macam bentuk geometri, seperti segitiga, lingkaran, segiempat.

b. Pengenalan warna. Manfaat lain dari Mozaik kita bisa membuat bahan/media dengan berbagai macam warna yang menarik untuk anak sekaligus dapat mengenalkan warna pada anak.

c. Melatih kreatifitas. Kegiatan Mozaik bermanfaat untuk melatih kreatifitas guru dan anak dalam berbagai bentuk dengan media yang bermacam-macam.

d. Melatih motorik halus. Kegiatan Mozaik bermanfaat mengembangkan motorik halusnya, karena dalam kegiatan ini anak menggunkan jari jemari untuk mengambil benda-benda kecil dan melibatkan koordinasi otot-otot tangan dan mata.

e. Melatih emosi. Karena dalam kegiatan ini anak akan melatih kesabaran dan emosinya. 
Meningkatkan Kemampuan Motorik Halus Anak Melalui Teknik Mozaik di Raudhatul Athfal Nurul Huda Kecamatan Sunggal kabupaten Deli Serdang (Juli Maini Sitepu \& Sri Rahayu Janita)

f. Mengenal konsep geometri. Dalam kegiatan Mozaik ada berbagai macam bentuk dan itu bisa sebagai pengenalan konsep geometri, seperti : segitiga, segiempat, lingkaran.

Selain manfaat Mozaik juga terdapat tujuan Mozaik. Tujuan membuat gambar teknik Mozaik dengan memakai berbagai bentuk/bahan (segitiga, segi empat, lingkaran dan lain lain), diantaranya : (1) mengembangkan imajinasi anak, (2) mengembangkan kreativitas anak, (3) melatih kesabaran dan ketelitian, (4) mengembangkan estetika dan keindahan, (5) mengembangkan motorik halus.

Dalam teknik guru harus memperhatikan cara/teknik pembuatan Mozaik yang benar agar kegiatan ini bermanfaat bagi perkembangan motorik halusnya.Manfaat dan tujuan Mozaik dalam penelitian ini adalah untuk melatih koordinasi mata dan jari jemari tangan anak dungan cara mengambil benda kecil dengan dua jari dan menempel benda kecil dengan tepat, rapi.

\section{Pembahasan dan Hasil}

Jenis penelitian yang digunakan adalah Penelitian Tindakan Kelas (PTK) atau Classroom Action Research (CAR) yang dilakukan di Raudhatul Atfal Nurul Huda Kecamatan Sunggal Kabupaten Deli Serdang.

\section{Siklus I}

Presentase Penilaian Siklus I

Meningkatkan Kemampuan Motorik Halus Anak Melalui Teknik Mozaik

\begin{tabular}{|c|c|c|c|c|c|c|}
\hline \multirow[t]{2}{*}{ No } & \multirow[t]{2}{*}{ 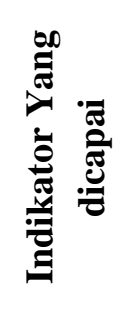 } & 产 & 离 & 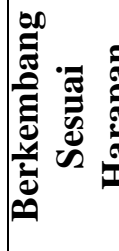 & 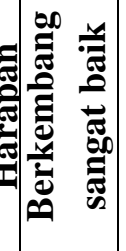 & 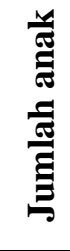 \\
\hline & & $\mathrm{F} 1$ & $\mathrm{~F} 2$ & F3 & F4 & $\%$ \\
\hline \multirow[b]{2}{*}{1} & \multirow{2}{*}{$\begin{array}{c}\text { Cara } \\
\text { Menjipl } \\
\text { ak/Men } \\
\text { ebalkan } \\
\text { Pola }\end{array}$} & 5 & 5 & 7 & 3 & 20 \\
\hline & & $\begin{array}{l}25 \\
\%\end{array}$ & $25 \%$ & $35 \%$ & $\begin{array}{l}15 \\
\%\end{array}$ & $\begin{array}{c}100 \\
\%\end{array}$ \\
\hline \multirow[b]{2}{*}{2} & \multirow{2}{*}{$\begin{array}{c}\text { Cara } \\
\text { Mengg } \\
\text { unting } \\
\text { Pola }\end{array}$} & 6 & 7 & 4 & 3 & 20 \\
\hline & & $\begin{array}{l}30 \\
\%\end{array}$ & $35 \%$ & $20 \%$ & $\begin{array}{l}15 \\
\%\end{array}$ & $\begin{array}{c}100 \\
\%\end{array}$ \\
\hline \multirow[b]{2}{*}{3} & \multirow{2}{*}{$\begin{array}{c}\text { Cara } \\
\text { Menju } \\
\text { mput } \\
\text { Pola }\end{array}$} & 4 & 7 & 5 & 4 & 20 \\
\hline & & $\begin{array}{l}20 \\
\%\end{array}$ & $35 \%$ & $25 \%$ & $\begin{array}{l}20 \\
\%\end{array}$ & $\begin{array}{c}100 \\
\%\end{array}$ \\
\hline \multirow[b]{2}{*}{4} & \multirow[b]{2}{*}{$\begin{array}{c}\text { Cara } \\
\text { Menem } \\
\text { pel Pola }\end{array}$} & 5 & 7 & 5 & 3 & 20 \\
\hline & & $\begin{array}{l}25 \\
\%\end{array}$ & $35 \%$ & $25 \%$ & $\begin{array}{l}15 \\
\%\end{array}$ & $\begin{array}{c}100 \\
\%\end{array}$ \\
\hline
\end{tabular}

Persentase berdasarkan Berkembang Sesuai Harapan - Berkembang Sangat BaikSiklus

I Meningkatkan Kemampuan Motorik Halus Anak Melalui Teknik Mozaik 
Intiqad Vol. 8 No. 2 Desember 2016: 73 - 83

\begin{tabular}{|c|c|c|c|c|}
\hline \multirow[t]{2}{*}{ No. } & \multirow[t]{2}{*}{ 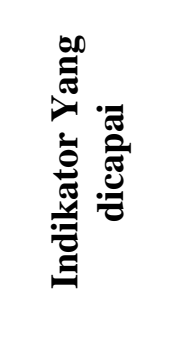 } & 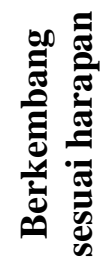 & 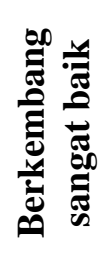 & 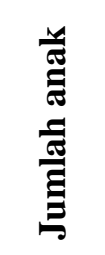 \\
\hline & & F3 & F4 & $\%$ \\
\hline \multirow[b]{2}{*}{1} & \multirow{2}{*}{$\begin{array}{c}\text { Cara } \\
\text { Menjiplak } \\
\text { /Menebal } \\
\text { kan Pola }\end{array}$} & 7 & 3 & 10 \\
\hline & & $35 \%$ & $15 \%$ & $50 \%$ \\
\hline \multirow[b]{2}{*}{2} & \multirow{2}{*}{$\begin{array}{c}\text { Cara } \\
\text { Menggunt } \\
\text { ing Pola }\end{array}$} & 4 & 3 & 7 \\
\hline & & $20 \%$ & $15 \%$ & $35 \%$ \\
\hline \multirow[b]{2}{*}{3} & \multirow{2}{*}{$\begin{array}{c}\text { Cara } \\
\text { Menjump } \\
\text { ut Pola }\end{array}$} & 5 & 4 & 9 \\
\hline & & $25 \%$ & $20 \%$ & $45 \%$ \\
\hline \multirow[b]{2}{*}{4} & \multirow{2}{*}{$\begin{array}{c}\text { Cara } \\
\text { Menempe } \\
1 \text { Pola }\end{array}$} & 5 & 3 & 8 \\
\hline & & $25 \%$ & $15 \%$ & 40 \\
\hline
\end{tabular}

Hasil rata-rata kemampuan motorik halus anak melalui teknik mozaik pada kondisi siklus I adalah 42,5\%

\section{Siklus II}

Presentase Penilaian Siklus II Kemampuan Motorik Halus Anak Melalui Teknik Mozaik

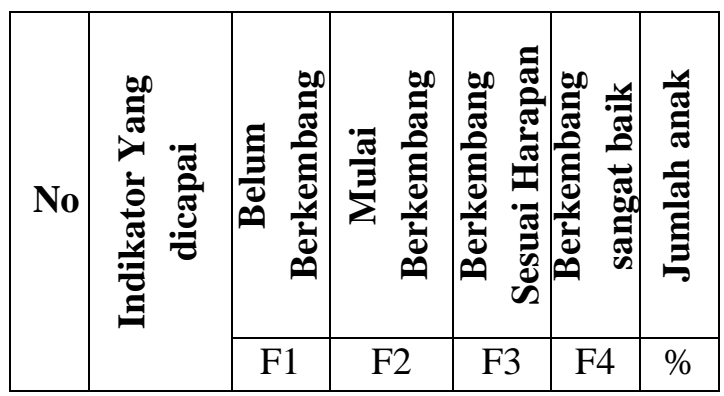

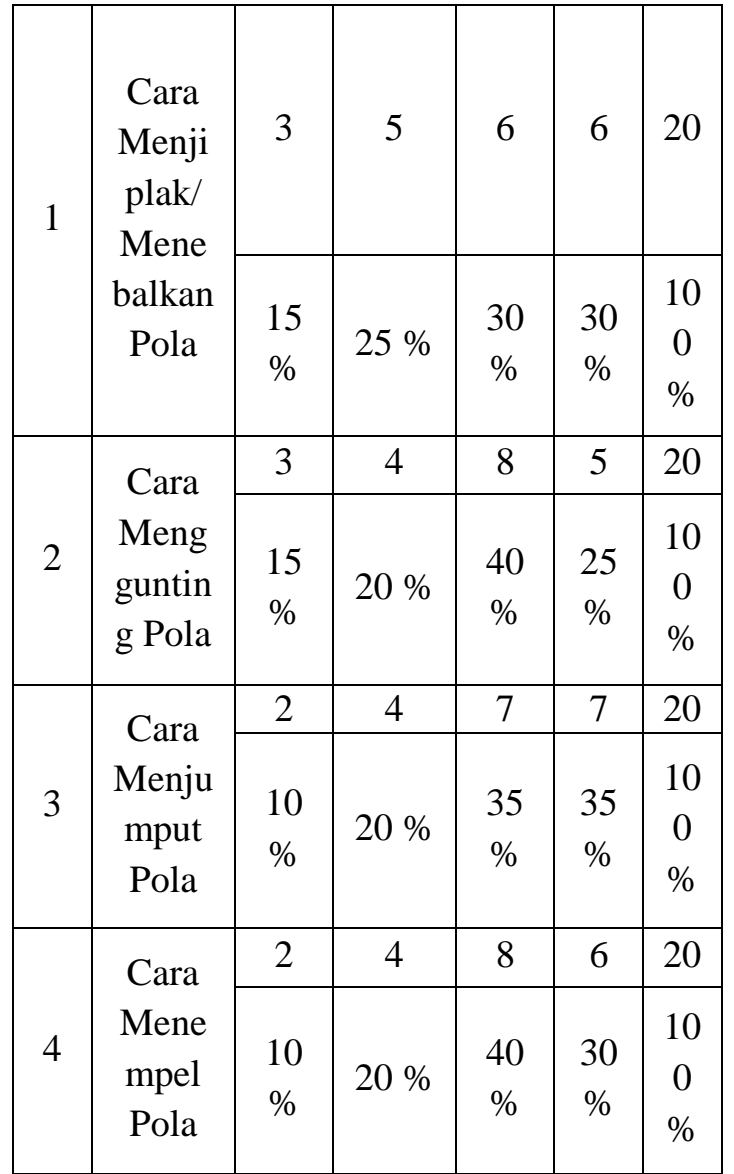

Persentase berdasarkan berkembang Sesuai Harapan - Berkembang Sangat BaikSiklus II Meningkatkan Kemampuan Motorik Halus Anak Melalui Teknik Mozaik

\begin{tabular}{|c|c|c|c|c|}
\hline \multirow[t]{2}{*}{ No } & 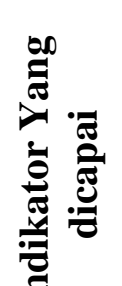 & 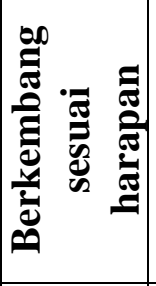 & 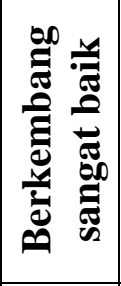 & 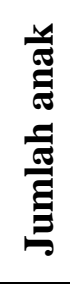 \\
\hline & & F3 & $\mathrm{F} 4$ & $\%$ \\
\hline 1 & Cara & 6 & 6 & 12 \\
\hline
\end{tabular}


Meningkatkan Kemampuan Motorik Halus Anak Melalui Teknik Mozaik di Raudhatul Athfal Nurul Huda Kecamatan Sunggal kabupaten Deli Serdang (Juli Maini Sitepu \& Sri Rahayu Janita)

\begin{tabular}{|c|c|c|c|c|}
\hline & $\begin{array}{c}\text { Menjiplak/ } \\
\text { Menebalka } \\
\text { n Pola }\end{array}$ & $30 \%$ & $30 \%$ & $\begin{array}{l}60 \\
\%\end{array}$ \\
\hline \multirow[b]{2}{*}{2} & \multirow{2}{*}{$\begin{array}{c}\text { Cara } \\
\text { Menggunti } \\
\text { ng Pola }\end{array}$} & 8 & 5 & 13 \\
\hline & & $40 \%$ & $25 \%$ & $\begin{array}{l}65 \\
\%\end{array}$ \\
\hline \multirow[b]{2}{*}{3} & \multirow{2}{*}{$\begin{array}{c}\text { Cara } \\
\text { Menjumput } \\
\text { Pola }\end{array}$} & 7 & 7 & 14 \\
\hline & & $35 \%$ & $35 \%$ & $\begin{array}{l}70 \\
\%\end{array}$ \\
\hline \multirow[b]{2}{*}{4} & \multirow{2}{*}{$\begin{array}{c}\text { Cara } \\
\text { Menempel } \\
\text { Pola }\end{array}$} & 8 & 6 & 14 \\
\hline & & $40 \%$ & $30 \%$ & $\begin{array}{l}70 \\
\%\end{array}$ \\
\hline
\end{tabular}

Hasil rata-rata kemampuan motorik halus anak melalui teknik mozaik pada kondisi siklus II adalah 66,25\%.

\section{Siklus III}

Presentase Penilaian Siklus III Kemampuan Motorik Halus Anak Melalui Teknik Mozaik

\begin{tabular}{|c|c|c|c|c|c|c|}
\hline \multirow[t]{2}{*}{ No } & \multirow{2}{*}{ 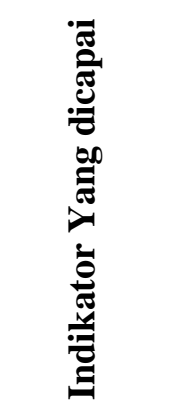 } & 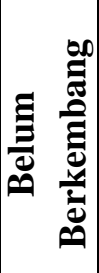 & 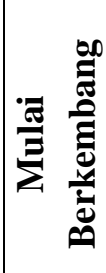 & 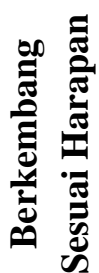 & 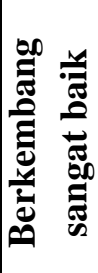 & 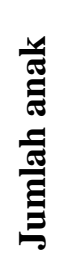 \\
\hline & & $\mathrm{F} 1$ & F2 & F3 & F4 & $\%$ \\
\hline \multirow[b]{2}{*}{1} & \multirow{2}{*}{$\begin{array}{c}\text { Cara } \\
\text { Menjiplak } \\
\text { /Menebal } \\
\text { kan Pola }\end{array}$} & 1 & 2 & 8 & 9 & 20 \\
\hline & & $5 \%$ & $\begin{array}{l}10 \\
\%\end{array}$ & $\begin{array}{l}40 \\
\%\end{array}$ & $\begin{array}{l}45 \\
\%\end{array}$ & $\begin{array}{c}10 \\
0 \\
\%\end{array}$ \\
\hline
\end{tabular}

\begin{tabular}{|c|c|c|c|c|c|c|}
\hline \multirow{2}{*}{2} & $\begin{array}{c}\text { Cara } \\
\text { Menggunt } \\
\text { ing Pola }\end{array}$ & $\begin{array}{c}10 \\
\%\end{array}$ & $\begin{array}{c}10 \\
\%\end{array}$ & $\begin{array}{c}45 \\
\%\end{array}$ & $\begin{array}{c}35 \\
\%\end{array}$ & $\begin{array}{c}10 \\
0 \\
\%\end{array}$ \\
\hline \multirow{2}{*}{3} & $\begin{array}{c}\text { Cara } \\
\text { Menjump } \\
\text { ut Pola }\end{array}$ & 1 & 2 & 7 & 10 & 20 \\
\hline & $\begin{array}{c}\text { Cara } \\
\text { Menempe } \\
1 \text { Pola }\end{array}$ & $5 \%$ & 10 & 35 & 50 & $\begin{array}{c}10 \\
0 \\
\%\end{array}$ \\
\cline { 3 - 7 } & & 15 & 40 & 40 & $\begin{array}{c}10 \\
0 \\
\%\end{array}$ \\
\hline
\end{tabular}

Persentase berdasarkan Berkembang Sesuai Harapan - Berkembang Sangat BaikSiklus III Meningkatkan Kemampuan Motorik Halus Anak Melalui Teknik Mozaik

\begin{tabular}{|c|c|c|c|c|}
\hline \multirow[t]{2}{*}{ No } & \multirow{2}{*}{ 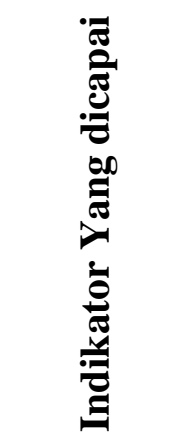 } & 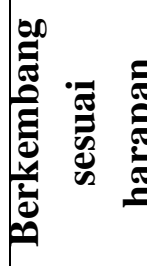 & 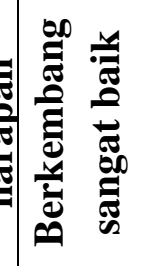 & 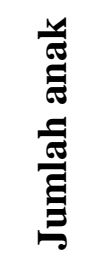 \\
\hline & & F3 & $\mathrm{F} 4$ & $\%$ \\
\hline \multirow{2}{*}{1} & \multirow{2}{*}{$\begin{array}{c}\text { Cara } \\
\text { Menjiplak/ } \\
\text { Menebalka } \\
\text { n Pola }\end{array}$} & 8 & 9 & 17 \\
\hline & & $40 \%$ & $45 \%$ & $85 \%$ \\
\hline \multirow{2}{*}{2} & \multirow{2}{*}{$\begin{array}{c}\text { Cara } \\
\text { Menggunti } \\
\text { ng Pola }\end{array}$} & 9 & 7 & 16 \\
\hline & & $45 \%$ & $35 \%$ & $80 \%$ \\
\hline 3 & Cara & 7 & 10 & 17 \\
\hline
\end{tabular}


Intiqad Vol. 8 No. 2 Desember 2016: 73 - 83

\begin{tabular}{|c|c|c|c|c|}
\hline & $\begin{array}{c}\text { Menjumpu } \\
\mathrm{t} \text { Pola }\end{array}$ & $35 \%$ & $50 \%$ & $85 \%$ \\
\hline 4 & $\begin{array}{c}\text { Cara } \\
\text { Menempel } \\
\text { Pola }\end{array}$ & $40 \%$ & $40 \%$ & $80 \%$ \\
\cline { 3 - 5 }
\end{tabular}

Hasil rata-rata kemampuan motorik halus anak melalui teknik mozaik pada kondisi siklus II adalah 82,5.

\section{Kesimpulan}

Berdasarkan hasil penelitian yang dilaksanakan selama tiga siklus maka dapat disimpulkan bahwa kegiatan melalui teknik mozaik dapat meningkatkan kemampuan motorik halus anak. Proses penelitian pada siklus pertama sampai siklus ketiga terlaksana dengan baik. Peningkatan kemempuan motorik halus anak melalui teknik mozaik sangat meningkat. Pada siklus pertama 42,5\%, pada siklus kedua kemampuan motorik halus anak meningkat menjadi $66,25 \%$ dan pada siklus ketiga sudah terlihat peningkatan yang signifikan yaitu menjadi $82,50 \%$.

Dengan demikian dapatlah dinyatakn bahwa PTK dengan teknik mozaik yang dilakukan dapat meningkatkan kemampuan motorik halus anak di Raudhatul Athfal Nurul Huda Kecamatan Sunggal Kabupaten Deli Serdang.

\section{Daftar Pustaka}

Affandi, M. H. 2006.

Seni Menggambar dan Kerajinan
Tangan. Yogyakarta : PGTKI Press

Arikunto , Suharsimi, dkk. 2008. Penelitian Tindakan Kelas. Jakarta : PT. Bumi Aksara

Decaprio, Richard. 2013. Aplikasi Teori Pembelajaran Motorik di Sekolah. Yogyakarta : Diva Press Departemen Pendidikan Nasional. 2004. Kurikulum TK dan RA Standar Kompetensi. Jakarta : Direktorat Pendidikan TK dan SD Departemen Pendidikan Nasional. 2010. Peraturan Menteri Pendidikan Nasional RI No 58 tentang Standar Pendidikan Anak Usia Dini (PAUD). Jakarta : Direktorat Pembinaan TK dan SD Hasanah, Uswatun. 2013. Identifikasi Pengembangan Motorik Halus Menggunakan Kegiatan Mozaik Anak TK Kelompok B di Gugus II Kecamatan Sanden Bantul. Skripsi. Yogyakarta : PG PAUD FIP UNIY

Hourlock, B Elisabeth. 1996. Perkembangan Anak Jilid I, edisi ke VI. Jakarta : PT. Gelora Aksara Pratama

Kurikulum Raudhatul Atfal. 2011. Pedoman Penggabungan Program Pembelajaran. Jakarta : Direktorat Pendidikan Madrasah, Kementerian Agama RI Jamaris, Martini.2003. Perkembangan dan Pengembangan Anak Usia 
Meningkatkan Kemampuan Motorik Halus Anak Melalui Teknik Mozaik di Raudhatul Athfal Nurul Huda Kecamatan Sunggal kabupaten Deli Serdang (Juli Maini Sitepu \& Sri Rahayu Janita)

Taman Kanak-kanak. Jakarta : PT. Grasindo

Muharrar, Syakir \& Verayanti, Sri. 2013. Kreasi Kolase, Montase, Mozaik Sederhana. Jakarta : Erlangga

Mustofa, Yasin. 2007. EQ Untuk Anak Usia Dini Dalam Pendidikan Islam. Yogyakarta : Sketsa

Novikasari, Mely. 2012. Kolase, Mozaik dan Montase, Diakses dari

http://melyloelhabox.blogspot.co. id/2012/10/kolase-mozaik-danmontase.html, pada tanggal 05 April 2016 Pukul 03.05 WIB

Nuraida, Nia. 2012. Meningkatkan Keterampilan Motorik Halus melalui Metode Demonstrasi di TK Ilam Terpadu At-Taqwa. Jurnal Penelitian. Bandung : UPI

Nurhajiyah, Siti. 2012. Peningkatan Motorik Halus Melalui Aktivitas Menggambar Pada Anak Kelompok B Di TK ABA Bogoran Trirenggo Bantul. Skripsi. Yogyakarta : PG PAUD FIP UNIY

Purwodarminto. 2001.Kamus Besar Bahasa Indonesia. Jakarta : Balai Pustaka

Saputra, M, Yuda. 2005. Pembelajaran Kooperatif Untuk Meningkatkan Keterampilan Anak TK. Yogyakarta : FIP UNIY
Soemarjadi, dkk. 1992. Pendidikan Keterampilan. Jakarta : Departemen Pendidikan Nasional Direktorat Jenderal Pendidikan Tinggi Rektorat Pembinaaan Pendidikan Tenaga Kependidikan dan Ketenagaan Perguruan Tinggi Syafaruddin, dkk. 2013. Profesi Keguruan \& Pendalaman Materi Raudhatul Atfal. Medan : Fakultas Ilmu Tarbiah dan Keguruan, IAIN

Sumanto. 2005. Pengembangan Kreativitas Seni Rupa Anak TK. Jakarta : Departemen Pendidikan Nasional

Sumantri, MS. 2010. Model Pengembangan Keterampilan Motorik Anak Usia Dini. Jakarta : Depdiknas, Dirjen Dikti

Suyadi. 2010. Psikologi Belajar PAUD. Yogyakarta : PT. Bintang Pustaka Abadi

Trianto. 2011. Desain Pengembangan Pembelajaran Tematik. Jakarta : Prenada Media Group

Wuryandari, Wuri. 2010. Penanaman Nilai Moral Untuk Anak Usia Dini. Jawa Barat : PG TK IT Pusda. 